\title{
Kontribusi wisata bahari \\ terhadap kesejahteraan masyarakat pesisir pulau Nusa Penida, Klungkung
}

\author{
Ni Made Santi, Yulius Hero, Hadi Susilo Arifin \\ Institut Pertanian Bogor \\ Email:nmshantii@yahoo.com
}

\begin{abstract}
Bali's marine resources is an important economy asset as well as food resource for local community and marine tourism. Nusa Penida Island is located in Nusa Penida District, Klungkung Region, Bali Province. It is belonging to the coral triangle area, the highest marine biodiversity in the world. Based on Decision Letter from Ministry of Marine and Fishery number 24/2014 about Nusa Penida Marine Conservation Area in Klungkung Region, Nusa Penida marine area was designated as Marine Tourism Park. Most of coastal communities in Nusa Penida are seaweed farmer. Marine tourism activity has significant impact for community's life. Integrated development is required to be done for its sustainability. The objective of this study is to analyze marine tourism contribution for community's prosperity in coastal area of Nusa Penida Island. Purposive sampling is chosen to collecting field data trough interview and questionnaire in 30 respondents and analyzed used BPS's indicator (2011). As much as $90 \%$ of coastal community in Nusa Penida is categorized in moderate living condition. Marine tourism activity contributes about $36 \%$ of local income, it's mean that marine tourism activity in Nusa Penida give positive contribution for local communities' prosperity.
\end{abstract}

Keywords: Coastal community, marine tourism, Nusa Penida Island, prosperity

\begin{abstract}
Abstrak
Sumberdaya laut Bali menjadi aset ekonomi penting sebagai sumber pangan bagi masyarakat lokal maupun wisata bahari. Pulau Nusa Penida terletak di Kecamatan Nusa Penida, Kabupaten Klungkung. Nusa Penida merupakan kawasan segitiga karang (the coral triangle) dengan keanekaragaman laut tertinggi di dunia. Berdasarkan Keputusan Menteri Kelautan dan Perikanan Nomor 24
\end{abstract}


Tahun 2014 tentang Kawasan Konservasi Perairan Nusa Penida Kabupaten Klungkung di Provinsi Bali, Nusa Penida merupakan kawasan konservasi dengan status taman wisata perairan. Sebagian besar masyarakat pesisir Pulau Nusa Penida bermata pencaharian sebagai petani rumput laut. Adanya kegiatan wisata bahari memiliki pengaruh terhadap kehidupan masyarakat, sehingga pengembangan secara terpadu perlu dilakukan untuk keberlanjutannya. Penelitian ini bertujuan untuk mengetahui kontribusi wisata bahari terhadap kesejahteraan masyarakat di kawasan pesisir Pulau Nusa Penida. Metode yang digunakan adalah purposive sampling melalui wawancara dan kuesioner terhadap 30 responden. Data yang diperoleh diolah menggunakan analisis kesejahteraan berdasarkan indikator Badan Pusat Statistik (2011). Sebesar 90\% masyarakat pesisir Pulau Nusa Penida berada dalam taraf hidup kesejahteraan sedang. Kontribusi pendapatan masyarakat dari sektor wisata bahari rata-rata mencapai $36 \%$. Hal ini menunjukkan bahwa kegiatan wisata bahari di kawasan pesisir Pulau Nusa Penida memberikan kontribusi positif terhadap kesejahteraan masyarakat disekitarnya.

Kata kunci: Kesejahteraan, masyarakat pesisir, Pulau Nusa Penida, wisata bahari

\section{Pendahuluan}

Tndustri pariwisata relatif tidak terpengaruh terhadap kondisi 1 perekonomian dunia yang tidak stabil. Oleh karena itu, sektor pariwisata sangat besar potensinya untuk dijadikan komoditi utama sebuah negara (UNWTO 2013). Saat ini setiap negara mengembangkan industri pariwisata sebagai penghasil devisa non-migas dalam bentuk budaya dan alam yang memiliki ciri khas untuk menunjang pariwisata dunia (Ferdinandus dan Suryasih 2014). Pulau Bali merupakan salah satu tujuan wisata terkemuka di dunia karena budaya masyarakatnya yang unik. Daerah pesisir dan laut yang mengelilingi Pulau Bali merupakan ekosistem yang sangat produktif. Jumlah kunjungan wisatawan mancanegara pada Tahun 2016 mencapai 4.927.937 kunjungan atau naik 23,14\% dibandingkan tahun 2015 yang berjumlah 4.001 .845 kunjungan (Disparda 2017).

Perairan Nusa Penida merupakan bagian dari kawasan 
segitiga terumbu karang (the coral triangle) yaitu sebuah kawasan yang memiliki keanekaragaman laut tertinggi di dunia. Ikan mola (Mola mola) merupakan icon bawah laut di Perairan Nusa penida yang dapat ditemui pada waktu yang dapat diprediksi, biasanya di bulan Juli-September setiap tahunnya. Sehingga pada bulan tersebut banyak sekali penyelam dari seluruh dunia yang datang ke Pulau Nusa Penida. Selain itu yang menjadi primadona sepanjang waktu di Perairan Nusa Penida yaitu ikan pari manta (Manta birostris) yang dapat dilihat tanpa harus melakukan scuba diving. Hal inilah yang menyebabkan kawasan perairan Nusa Penida sangat perlu untuk dikonservasi (Welly et al. 2011).

Kabupaten Klungkung merupakan salah satu wilayah di Bali dengan persentase penduduk miskin tertinggi setelah Kabupaten Karangasem. Jumlah penduduk miskin tertinggi adalah di Kecamatan Nusa Penida sebanyak 3.034 orang (Purbadharmaja et al 2014). Angka tersebut menunjukkan bahwa Kecamatan Nusa Penida merupakan penyumbang hampir sebagian penduduk miskin di Kabupaten Klungkung. Masyarakat hidup sangat tradisional dengan berbagai keterbatasan, misalnya kesulitan mendapatkan air bersih karena sumber air berada di daerah curam dan sangat sulit untuk diakses ditambah dengan curah hujan di Bali yang rendah. Masyarakat masih banyak bergantung pada air hujan untuk keperluan minumnya sehari-hari. Keadaan topografi Nusa Penida yang rumit menjadikan daerah ini kesulitan untuk mengembangkan budidaya pertanian, hampir $75 \%$ bahan pangan didatangkan dari Bali daratan. BPS (2015) mendata terdapat 7475 rumah tangga sasaran (RTS) di Pulau Nusa Penida yang akan dijadikan dasar untuk meningkatkan kesejahteraan masyarakat di bidang ekonomi. Desa Batukandik memiliki jumlah terbanyak sebesar 919 RTS, sedangkan Kampung Toyapakeh memiliki jumlah terkecil sebesar 19 RTS. Tujuan penelitian ini adalah mengkaji kontribusi wisata bahari terhadap tingkat kesejahteraan masyarakat di kawasan pesisir Pulau Nusa Penida.

Meskipun sejak 10 tahun terakhir pembangunan di wilayah ini sangat pesat, namun masih banyak masyarakat yang belum merasakan dampak tersebut. Kegiatan pariwisata di Pulau Nusa Penida dapat memberikan manfaat kepada masyarakat setempat, pemerintah dan pihak swasta. Pengembangan pariwisata memiliki manfaat penting untuk peningkatkan penghasilan 
kawasan dan terciptanya kesempatan kerja bagi penduduk lokal untuk meingkatkan kesejahteraan masyarakat, namun disisi lain dihadapkan pada berbagai permasalahan seperti sumberdaya alam maupun sumberdaya manusia. Pengembangan pariwisata secara berkelanjutan perlu dilakukan untuk mengurangi dampakdampak negatif (Perda Provinsi Bali No 16 Tahun 2009).

Penelitian ini bertujuan untuk mengetahui kontribusi wisata bahari terhadap kesejahteraan masyarakat di kawasan pesisir Pulau Nusa Penida. Potensi wisata di Nusa Penida sangat besar, terutama untuk wisata bahari. Dalam beberapa dekade terakhir, potensi itu sudah dikembangkan, seperti terlihat pada adanya kapal wisata yang menawarkan paket wisata sehari (day trip) dari Pelabuhan Benoa ke Nusa Lembongan, daerah Nusa Penida. Alam Nusa Penida juga indah, memikat wisatawan, selain daya tarik bahari. Sejauh mana daya tarik wisata bahari ini memberikan kontribusi pada kesejahteraan masyarakat menjadi pokok kajian artikel ini.

\section{Metode Penelitian}

Penelitian ini dilakukan pada bulan Mei sampai bulan Juli 2016 di Pulau Nusa Penida, Kecamatan Nusa Penida, Kabupaten Klungkung. Alat dan bahan yang digunakan dalam penelitian ini yaitu alat tulis, GPS, kamera, scuba set, tape recorder, lembar kuisioner dan peta kawasan Nusa Penida.

Pengumpulan sampel dilakukan dengan metode purposive sampling berdasarkan pertimbangan terhadap tujuan penelitian. Sampel yang digunakan sebanyak 30 responden terdiri dari masyarakat yang bekerja disektor wisata bahari yaitu pengelola penginapan, penjual cinderamata, petani rumput laut, nelayan, pemilik penyewaan kendaraan, tour guide dan pemilik rumah makan/ warung. Data diperoleh melalui wawancara dan kuesioner responden.

Data diambil meliputi karakteristik masyarakat seperti: umur, jumlah penduduk mata pencaharian, pendapatan rumah tangga, pengeluaran rumah tangga, kondisi tempat tinggal, fasilitas tempat tinggal, kesehatan anggota keluarga, kemudahan mendapatkan pelayanan kesehatan, kemudahan memasukkan anak ke jenjang pendidikan dan kemudahan mendapatkan akses transportasi. Kriteria kondisi tempat tinggal yang dinilai ada lima item yaitu jenis atap rumah, jenis dinding rumah, status kepemilikan rumah, 
jenis dan luas lantai rumah. Fasilitas tempat tinggal yang dinilai terdiri dari dua belas item yaitu pekarangan, alat elektronik, pendingin, penerangan, kendaraan yang dimiliki, bahan bakar untuk memasak, sumber air bersih, fasilitas air minum, cara memperoleh air minum, sumber air minum, WC dan jarak WC dari rumah. Kemudahan mendapatkan pelayanan kesehatan terdiri dari lima item yaitu jarak rumah sakit terdekat, jarak toko obat, penanganan obat-obatan, harga obat-obatan dan alat kontrasepsi. Kemudahan memasukkan anak ke jenjang pendidikan terdiri dari tiga item yaitu biaya sekolah, jarak ke sekolah dan proses penerimaan. Kemudahan mendapatkan transportasi terdiri dari tiga item yaitu ongkos kendaraan, fasilitas kendaraan dan status kepemilikan kendaraan.

Metode yang digunakan dalam penelitian adalah analisis deskriptif. Deskripsi dilakukan untuk menganalisis tingkat kesejahteraan Masyarakat Pesisir Pulau Nusa Penida berdasarkan indikator dari Badan Pusat Statistik (2011) (Tabel 1).

Tabel 1. Matriks penilaian indikator kesejahteraan masyarakat

\begin{tabular}{llc}
\hline Indikator kesejahteraan & Kriteria & Skor \\
\hline Pendapatan rumah & Tinggi (Rp4.100.001-Rp6.000.000) & 3 \\
tangga & Sedang (Rp2.200.001-Rp4.100.000) & 2 \\
& Rendah (Rp300.000-Rp2.200.000) & 1 \\
Pengeluaran rumah & Tinggi (Rp2.168.001-Rp3000.000) & 3 \\
tangga & Sedang (Rp1.334.001-Rp2.168.000) & 2 \\
& Rendah (Rp500.000-Rp1.334.000) & 1 \\
Kondisi tempat tinggal & Permanen (11-15) & 3 \\
& Semi permanan (6-10) & 2 \\
Fasilitas tempat tinggal & Non Permaen (1-5) & 1 \\
& Lengkap (33-44) & 3 \\
Kesehatan anggota & Cukup(23-33) & 2 \\
keluarga & Kurang (12-22) & 1 \\
\multirow{2}{*}{ Kemudahan } & Bagus (<25\%) & 3 \\
mendapatkan pelayanan & Cukup (25\%-50) & 2 \\
kesehatan & Kurang (>50\%) & 1 \\
& Mudah (16-20) & 3 \\
& Sulit (3-10) & 2 \\
\end{tabular}




\begin{tabular}{lll} 
Kemudahan & Mudah (7-9) & 3 \\
memasukkan anak ke & Cukup (5-6) & 2 \\
jenjang pendidikan & Sulit (3-4) & 1 \\
Kemudahan & Mudah (7-9) & 3 \\
mendapatkan akses & Cukup (5-6) \\
transportasi & Sulit (3-4) & 2 \\
\hline
\end{tabular}

Selanjutnya masing-masing kriteria tersebut diberi nilai kemudian dijumlahkan dan hasilnya diberi skor. Kriteria untuk masing-masing klasifikasi sebagai berikut:

Tingkat kesejahteraan tinggi : nilai skor 20-24

Tingkat kesejahteraan sedang : nilai skor 14-19

Tingkat kesejahteraan rendah : nilai skor 8-13

Sumber: Modifikasi Sugiharto (2007).

\section{Hasil Dan Pembahasan}

\subsection{Letak dan Keadaan Geografis}

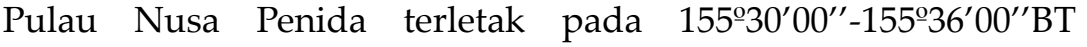
dan $8^{\circ} 40^{\prime} 00^{\prime \prime}-8^{\circ} 45^{\prime} 00^{\prime \prime}$ LS, Kecamatan Nusa Penida, Kabupaten Klungkung. Kecamatan Nusa Penida merupakan dua per tiga dari wilayah Kabupaten Klungkung dengan luas wilayah 202,84 $\mathrm{km}^{2}$ dan terdiri dari 16 desa. Kecamatan Nusa Penida terdiri dari tiga pulau utama yaitu Nusa Penida, Nusa Lembongan dan Nusa Ceningan. Jumlah penduduk Pulau Nusa Penida sebesar 57.081 orang.

\subsection{Tingkat Kesejahteraan Masyarakat}

Kesejahteraan berarti sebuah kondisi dimana seseorang dapat memenuhi kebutuhan pokok, baik itu kebutuhan sandang, pangan, papan, air minum yang bersih, kesempatan melanjutkan pendidikan dan memiliki pekerjaan yang layak. Kesejahteraan masyarakat atau kesejahteraan sosial menurut Undang-Undang Nomor 11 Tahun 2009 yaitu kondisi terpenuhinya kebutuhan material, spiritual dan sosial warga negara agar dapat hidup layak dan mampu mengembangkan diri, sehingga dapat melaksanakan fungsi sosialnya.

Tingkat kemiskinan dapat diukur melalui konsep kemampuan memenuhi kebutuhan dasar (basic needs approach). Kemiskinan 
yang melanda masyarakat pesisir disebabkan oleh faktor-faktor kompleks. Kesejahteraan sangat tergantung dari jumlah pendapatan yang diperoleh dan bersumber dari usaha yang dilakukan berupa upah, laba atau bunga (Kusnadi 2002). Masyarakat pesisir merupakan kelompok orang yang tinggal di daerah pesisir dan bergantung secara langsung pada pemanfaatan sumberdaya laut dan pesisir untuk keberlangsungan hidupnya. Yang termasuk ke dalam masyarakat pesisir antaralain nelayan, buruh nelayan, pembudidaya organisme laut, pedagang, pengolah hasil tangkap laut, buruh jasa wisata, buruh transportasi, penjual cinderamata dan lain-lain. Pokok yang digali adalah Pendapatan (A), Konsumsi atau pengeluaran rumah tangga (B), Kondisi tempat tinggal (C), Fasilitas tempat tinggal (D), Kesehatan anggota keluarga (E), Kemudahan mendapatkan fasilitas kesehatan (F). Rekapitulasi tanggapan responden dapat dilihat pada Tabel 2.

Tabel 2. Rekapitulasi tanggapan responden

\begin{tabular}{|c|c|c|c|c|c|c|c|c|c|c|}
\hline \multirow[t]{2}{*}{ No } & \multicolumn{8}{|c|}{ Skor } & \multirow[t]{2}{*}{ Jumlah } & \multirow[t]{2}{*}{ Kriteria } \\
\hline & A & B & C & D & E & $\mathrm{F}$ & G & $\mathrm{H}$ & & \\
\hline 1. & 1 & 1 & 3 & 2 & 3 & 2 & 2 & 2 & 16 & Sedang \\
\hline 2. & 1 & 2 & 3 & 2 & 3 & 2 & 2 & 2 & 17 & Sedang \\
\hline 3. & 1 & 1 & 3 & 2 & 3 & 2 & 3 & 3 & 18 & Sedang \\
\hline 4. & 1 & 1 & 3 & 2 & 3 & 2 & 3 & 3 & 18 & Sedang \\
\hline 5. & 1 & 1 & 3 & 2 & 3 & 2 & 3 & 3 & 18 & Sedang \\
\hline 6. & 1 & 2 & 3 & 1 & 1 & 1 & 2 & 2 & 13 & Rendah \\
\hline 7. & 1 & 1 & 3 & 2 & 3 & 2 & 3 & 3 & 18 & Sedang \\
\hline 8. & 2 & 2 & 3 & 2 & 3 & 2 & 2 & 3 & 19 & Sedang \\
\hline 9. & 1 & 2 & 3 & 2 & 3 & 1 & 3 & 2 & 17 & Sedang \\
\hline 10. & 1 & 1 & 3 & 2 & 1 & 2 & 2 & 3 & 15 & Sedang \\
\hline 11. & 1 & 2 & 3 & 2 & 1 & 2 & 3 & 2 & 16 & Sedang \\
\hline 12. & 1 & 2 & 3 & 2 & 1 & 2 & 3 & 2 & 16 & Sedang \\
\hline 13. & 1 & 3 & 3 & 2 & 3 & 1 & 3 & 2 & 18 & Sedang \\
\hline 14. & 1 & 2 & 3 & 2 & 3 & 2 & 2 & 3 & 18 & Sedang \\
\hline 15. & 1 & 2 & 3 & 2 & 3 & 2 & 2 & 2 & 17 & Sedang \\
\hline 16. & 1 & 2 & 3 & 2 & 1 & 2 & 3 & 3 & 17 & Sedang \\
\hline 17. & 1 & 1 & 3 & 1 & 1 & 1 & 3 & 1 & 12 & Rendah \\
\hline 18. & 3 & 3 & 2 & 2 & 1 & 2 & 3 & 3 & 19 & Sedang \\
\hline 19. & 1 & 1 & 3 & 2 & 3 & 2 & 2 & 3 & 17 & Sedang \\
\hline 20. & 1 & 1 & 3 & 2 & 3 & 2 & 3 & 3 & 18 & Sedang \\
\hline
\end{tabular}




\begin{tabular}{lllllllllll} 
21. & 1 & 2 & 3 & 2 & 3 & 2 & 3 & 3 & 19 & Sedang \\
22. & 1 & 2 & 3 & 2 & 3 & 2 & 2 & 3 & 18 & Sedang \\
23. & 1 & 2 & 3 & 2 & 3 & 2 & 3 & 3 & 19 & Sedang \\
24. & 1 & 2 & 3 & 2 & 3 & 2 & 3 & 3 & 19 & Sedang \\
25. & 1 & 1 & 3 & 2 & 3 & 2 & 2 & 3 & 17 & Sedang \\
26. & 1 & 2 & 3 & 2 & 3 & 2 & 2 & 3 & 18 & Sedang \\
27. & 1 & 2 & 3 & 2 & 3 & 1 & 3 & 3 & 18 & Sedang \\
28. & 2 & 3 & 3 & 2 & 3 & 2 & 3 & 3 & 21 & Tinggi \\
29. & 1 & 2 & 3 & 2 & 3 & 2 & 2 & 3 & 18 & Sedang \\
30. & 1 & 1 & 3 & 2 & 3 & 2 & 2 & 2 & 16 & Sedang \\
\hline
\end{tabular}

Sumber: Data Olahan 2017

Keterangan :
A : Pendapatan
$\mathrm{B}$ : Konsumsi atau pengeluaran rumah tangga
C : Kondisi tempat tinggal
D : Fasilitas tempat tinggal
E : Kesehatan anggota keluarga
F : Kemudahan mendapatkan fasilitas kesehatan
$\mathrm{G}$ : Kemudahan memasukkan anak ke jenjang pendidikan
$\mathrm{H}$ : Kemudahan mendapatkan fasilitas transportasi

Berdasarkan Tabel 3 diketahui bahwa 90\% responden atau sebanyak 27 orang tergolong dalam keluarga dengan tingkat kesejahteraan sedang, 1 responden atau 3,3\% berada dalam golongan keluarga dengan tingkat kesejahteraan tinggi dan 2 responden atau $6,7 \%$ berada dalam golongan keluarga dengan tingkat kesejahteraan rendah.

Tabel 3. Rekapitulasi tingkat kesejahteraan masyarakat di Pulau Nusa Penida

\begin{tabular}{lllll}
\hline No & Kategori & $\begin{array}{l}\text { J u m l a h J } \mathrm{u} \mathrm{m} \mathrm{l} \mathrm{a} \\
\text { Skor }\end{array}$ & $\begin{array}{l}\text { Responden } \\
\text { Rersen- } \\
\text { tase (\%) }\end{array}$ \\
\hline 1. & Tingkat kesejahteraan tinggi & $20-24$ & 1 & 3,3 \\
2. & Tingkat kesejahteraan sedang & $14-19$ & 27 & 90 \\
3. & Tingkat kesejahteraan rendah & $8-13$ & 2 & 6,7 \\
Jumlah & & 30 & 100 \\
\hline
\end{tabular}

Sumber: Data Olahan 2017 


\subsection{Mata Pencaharian Masyarakat}

Mata pencaharian sebagian besar masyarakat adalah petani atau pekebun dengan jumlah sebesar 19.675 jiwa dan jumlah tertinggi kedua adalah masyarakat yang belum atau tidak bekerja sebesar 13.448 jiwa (Gambar 1). Masyarakat yang bekerja sebagai pekebun adalah masyarakat yang tinggal di daerah perbukitan dan jauh dari pesisir. Mereka memilih menjadi pekebun karena topografi yang dikelilingi tebing berbatu yang curam dan gelombang air laut tinggi yang menyebabkan sulitnya mencapai bibir pantai, sehingga masyarakat hanya dapat memaksimalkan lahan di ladang dan perkebunan.

Hampir di seluruh bagian Pulau Nusa Penida memiliki kemiringan lereng 8-15\%, curah hujan yang sangat rendah, suhu udara yang tinggi dan kelembaban yang rendah menyebabkan Pulau Nusa Penida sangat sesuai sebagai lahan untuk tanaman pangan kering dan lahan untuk tanaman tahunan atau perkebunan. Ketersediaan air merupakan faktor pembatas dalam pengembangan pertanian di wilayah Nusa Penida. Sedangkan masyarakat yang lebih dekat pesisir lebih banyak menjadi petani rumput laut. Saat ini petani rumput laut di Pulau Nusa Penida belum dapat mengolah sendiri hasil budidaya mereka, hanya ada beberapa masyarakat yang mulai mengolah rumput laut untuk dijadikan kerupuk dan masih terbatas pada industri rumahan yang sangat kecil, karena hasil olahan rumput laut juga belum terlalu populer di Pulau Nusa Penida sehingga belum banyak yang melirik rumput laut untuk dijadikan industri. Perlu adanya pelatihan pengolahan rumput laut dan menggerakkan koperasi-koperasi usaha tani yang ada maupun yang sudah vakum untuk mendistribusikan hasil pengolahan rumput laut tersebut, sehingga masyarakat Nusa Penida dapat memproduksi sendiri hasil budidaya rumput laut dan dapat dipasarkan sebagai cinderamata atau paganan khas.

Dari hasil wawancara dengan responden menyatakan bahwa keterbatasan modal dan minimnya keterampilan serta pengetahuan masyarakat mengenai cara pengolahan rumput laut menyebabkan hasil panen rumput laut banyak yang terbuang karena membusuk, bahkan untuk dijadikan bahan konsumsi sendiri pun tidak bisa karena mereka tidak mengetahui bagaimana cara mengolahnya. Masyarakat hanya menunggu pengepul datang untuk menjual hasil panen dan dibayar dengan harga yang rendah. Harga beli rumput 
laut dari petani berkisar antara Rp 4.000,00/kg untuk rumput laut hitam dan Rp 7.000,00/kg untuk rumput laut hijau. Di Pulau Nusa Penida jumlah pengepul rumput laut sebanyak 5 orang. Hasil pengolahan rumput laut ini mendatang dapat dijadikan ciri khas Pulau Nusa Penida dan dapat menggerakkan masyarakat sebagai poros untuk menciptakan wisata bahari berbasis masyarakat

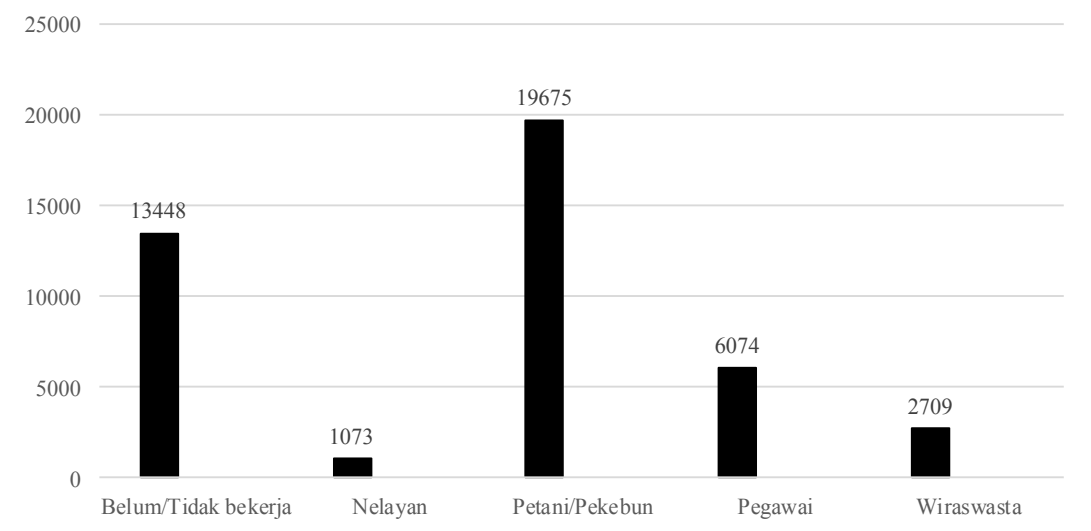

Gambar 1. Grafik mata pencaharian masyarakat di Pulau Nusa Penida

\subsection{Pendapatan dan Pengeluaran Rumah Tangga}

Tingkat pendapatan mempengaruhi pola dan tingkat pengeluaran sebab pendapatan merupakan faktor yang menentukan kuantitas dan kualitas konsumsi (Megawangi 1994). Berdasarkan data pada Tabel 2 diketahui bahwa pendapatan responden tergolong rendah dengan nilai skor rata-rata 1 dan interval pendapatan perbulan berkisar antara Rp300.000,00-Rp 2.200.000,00 dengan rata-rata sebesar Rp 1.250.000,00 per bulan. Sumber pendapatan rumah tangga didapat dari hasil perikanan, perkebunan dan pendapatan tambahan dari aktivitas wisata bahari. Pendapatan masyarakat dari sektor wisata bahari berkisar antara Rp 300.000,00 - Rp 600.000,00 perbulan dengan rata-rata sebesar Rp 450.000,00 perbulan. Kontribusi pendapatan dari sektor wisata bahari terhadap pendapatan total rata-rata sebesar $36 \%$. Pendapatan tersebut berupa upah yang didapat dari hasil menjadi pemandu wisata, menyewakan alat snorkeling, menyewakan kapal, menjual makanan dan minuman atau menyewakan kendaraan.

Sebagian besar responden menyatakan bahwa minimnya pendapatan yang diterima karena rata-rata masyarakat bekerja 
serabutan sehingga pendapatan yang diterima setiap bulan tidak menentu padahal pengeluaran perbulan semakin meningkat. Responden juga menyebutkan bahwa saat ini jumlah petani rumput laut semakin sedikit, seiring banyaknya objek wisata yang baru dibuka di Pulau Nusa Penida. Masyarakat lebih memilih bekerja di sektor pariwisata karena penghasilan yang lebih besar dibandingkan menjadi petani rumput laut.

Masyarakat banyak yang mencari pendapatan dengan berjualan minuman dan makanan ringan di kawasan pantai atau menyewakan sepeda motor yang dimiliki kepada wisatawan. Pendapatan masyarakat pesisir adalah pendapatan yang bersumber dari hasil tangkap, budidaya dan usaha lain diluar sektor perikanan. Peningkatan pendapatan cukup penting namun meningkatkan kesejahteraan keluarga tidak cukup tanpa disertai dengan perubahan perilaku masyarakat pesisir terutama dalam investasi seperti pendidikan dan kesehatan (Muflikhati et al 2010).
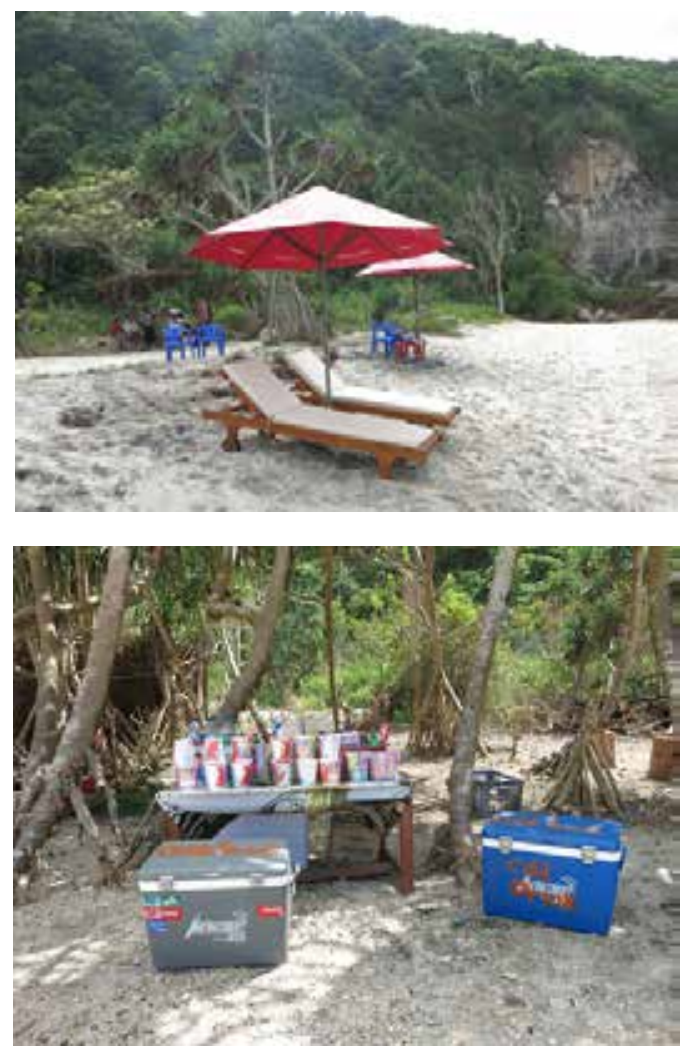

Gambar 2. Usaha masyarakat di kawasan pantai. 
Konsumsi atau pengeluaran rumah tangga responden tergolong sedang dengan nilai skor rata-rata 2. Pengeluaran berkisar antara Rp 1.334.001- Rp 2.168 .000 perbulan dengan ratarata sebesar Rp 1.443.333,00 perbulan. Responden menyebutkan bahwa pengeluaran rumah tangga mengalami peningkatan karena harga kebutuhan pokok dan kebutuhan lainnya semakin tinggi. Pengeluaran rumah tangga responden terdiri dari biaya konsumsi sehari-hari, biaya perawatan peralatan bertani rumput laut dan perkebunan, biaya listrik, kebutuhan anak-anak dan biaya tidak tetap lainnya seperti biaya yang harus dikeluarkan jika ada anggota keluarga yang sakit. Pengeluaran rumah tangga ini dipengaruhi juga oleh jumlah keluarga yang harus ditanggung oleh responden. Semakin banyak anggota keluarga maka semakin besar pula pengeluaran yang harus dibayar setiap bulan. Menurut Megawangi (1994) semakin besar jumlah anggota keluarga, cenderung semakin tidak ada pengaturan terhadap pengeluaran sehari-hari. Masyarakat ikut berkontribusi dalam aktivitas wisata bahari dan memperoleh manfaat sebagai peluang usaha dan mata pencaharian yang dapat meningkatkan pendapatan. Kondisi sosial ekonomi masyarakat mengalami peningkatan signifikan yang terlihat dari bertambahnya usaha dan pekerjaan.

\subsection{Kondisi Tempat Tinggal}

Kondisi tempat tinggal responden hampir seluruhnya sudah permanen dengan skor rata-rata 3. Tempat tinggal mereka sudah menggunakan atap dari genteng, dengan dinding tembok dan lantai semen berlapis keramik meskipun ada beberapa responden yang lantai rumahnya belum dilapisi keramik dengan luas lantai lebih dari $50 \mathrm{~m}^{2}$. Status kepemilikan lahan hampir seluruh responden adalah milik pribadi. Perbedaan antara masyarakat sejahtera dan belum sejahtera dicerminkan oleh pola konsumsinya. Pola konsumsi masyarakat yang belum sejahtera biasanya didominasi oleh kebutuhan primer sedangkan pola konsumsi masyarakat yang sudah sejahtera teralokasikan pada kebutuhan sekunder atau tersier (Shinta 2008).

Fasilitas tempat tinggal tergolong sedang dengan skor rata-rata 2. Rata-rata responden memiliki pekarangan yang sempit, namun mereka biasanya memiliki kebun atau ladang terpisah dari area rumah. Ada aturan adat yang melarang masyarakat di Pulau Nusa 
Penida untuk memelihara hewan di pekarangan rumah, apabila dilanggar masyarakat harus membayar sejumlah denda sebagai sangsi. Terdapat pecalang yang akan rutin berpatroli memeriksa keadaan tempat tinggal masyarakatnya. Perlengkapan elektronik yang dimiliki masyarakat didalam rumah rata-rata adalah $\mathrm{TV}$, radio, dan kulkas. Sumber penerangan yang dipakai adalah listrik dan sudah tersedia dalam 24 jam penuh. Bahan bakar yang digunakan rata-rata adalah gas LPG dan tidak terlalu sulit ditemukan meskipun masih ada masyarakat yang memanfaatkan kayu bakar dari ladang mereka sendiri untuk menghemat penggunaan gas LPG. Responden juga memiliki kendaraan berupa sepeda motor, sebab angkutan desa yang ada terbatas hanya mengantar sampai di pasar dan hanya sampai sore hari. Pada umumnya responden memiliki sarana mandi, cuci dan kakus (MCK) sendiri.

Kebutuhan air bersih digunakan untuk keperluan kesehatan, minum, masak, mencuci, mandi, mencuci alat makan dan minum, menyiram tanaman dan keperluan hewan ternak. Keberadaan air bersih di Pulau Nusa Penida menjadi masalah penting. Desa-desa yang berada di perbukitan sangat kesulitan mendapatkan air bersih. Sumber air tanah telah ditemukan di 8 desa di Kecamatan Nusa Penida dengan debit air mencapai 524,60 liter/detik. Sumur bor/gali lebih banyak terdapat di tepi pantai dengan potensi debit air antara 0,4 liter/detik. Sumber mata air lainnya berasal dari daerah aliran sungai. Namun, seluruh DAS di kawasan Nusa Penida merupakan jenis sungai musiman (intermitten) yang airnya tidak mengalir sepanjang tahun dan debit air bergantung pada curah hujan.

Daerah Pantai Suwehan, Pasih Uug serta Pantai Kelingking masih mengandalkan air hujan untuk kebutuhan sehari-hari, sehingga keberadaan air sangat tergantung dari musim. Masyarakat masih banyak yang mengandalkan sumur-sumur tadah hujan yang dibangun masyarakat untuk kebutuhan sehari-hari. Pada saat kemarau panjang atau kering masyarakat terpaksa harus membeli air. Lokasi sumber mata air yang sangat jauh dan berada di tebing atau lereng menyebabkan masyarakat sulit untuk menjangkaunya dan belum terdapat instalasi air dari sumber mata air menuju desa. Sedangkan daerah yang dekat dengan pesisir seperti kawasan Pantai Crystal Bay, Pantai Gamat, Pantai Atuh, Pantai Suana dan Pantai Toyapakeh lebih mudah untuk mendapatkan air. Air mengalir sepanjang tahun dengan volume yang cukup banyak. 
Hal ini juga yang menyebabkan ketimpangan sangat jelas terlihat di Pulau Nusa Penida sehingga pembangunan dan fasilitas wisata masih terpusat di beberapa lokasi.

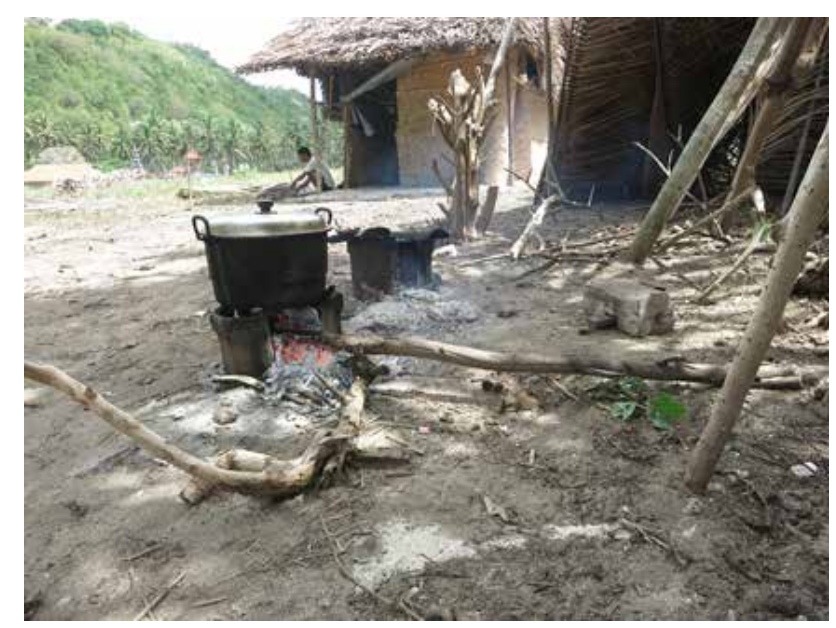

Gambar 3. Kayu sebagai bahan bakar

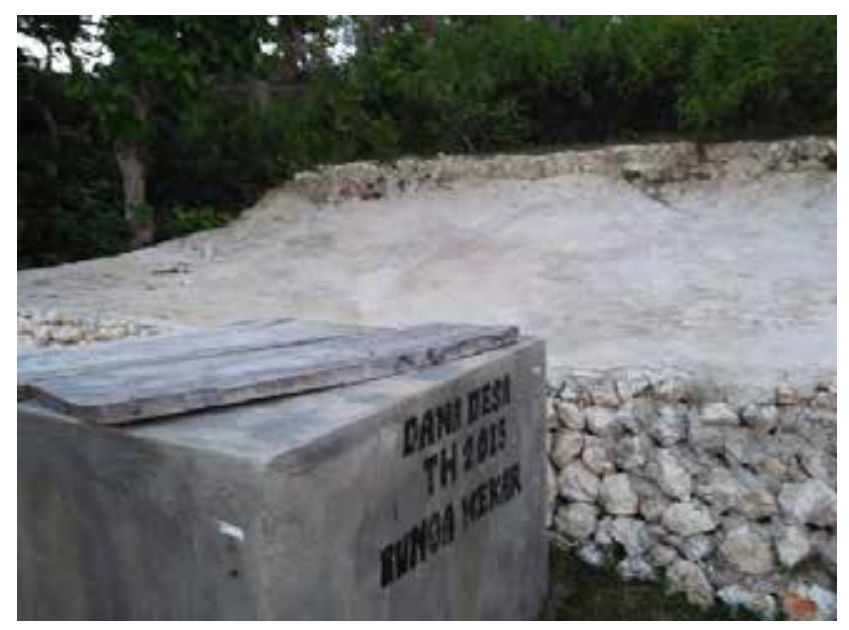

Gambar 4. Sumur tempat penampungan air hujan

Kemudahan mendapatkan sarana transportasi juga tidak menjadi masalah dengan nilai skor rata-rata 3, adanya angkutan desa yang dimiliki pribadi dan beroperasi sampai sore dengan harga yang terjangkau sangat membantu masyarakat dalam bepergian terutama bagi yang tidak memiliki kendaraan pribadi, 
untuk belanja maupun membawa barang dagangan hasil laut maupun kebun yang akan di jual di pasar.

\subsection{Tingkat Kesehatan dan Pendidikan Anggota Keluarga}

Kesehatan anggota keluarga tergolong cukup baik. Dalam setahun terakhir tidak pernah terjadi kekurangan bahan makanan lebih dari sebulan. Kemudahan mendapatkan fasilitas kesehatan didukung oleh adanya puskesmas di Desa Batununggul. Jarak tempuh menuju puskesmas bervariasi tergantung letak desa, namun terdapat puskesmas pembantu hampir di setiap desa. Untuk pos KB juga sudah terdapat di seluruh desa. Toko obat-obatan masih terpusat di Desa Batununggul dan Toyapakeh sehingga masih jauh untuk ditempuh dari desa lainnya, namun harga pelayanan kesehatan dan obat-obatan masih terjangkau meskipun belum lengkap. Untuk kebutuhan khusus masyarakat harus di rujuk ke rumat sakit di Bali daratan.

Tenaga kesehatan di Nusa Penida mayoritas terdiri dari tenaga kesehatan profesional yaitu dokter, bidan dan perawat. Namun tenaga kesehatan tradisional seperti dukun dan lainnya juga masih dipercaya oleh masyarakat. Bagi sebagian besar penduduk Indonesia pemeliharaan kesehatan masih bersifat kuratif sehingga biaya kesehatan merupakan pengeluaran tidak terduga namun memerlukan biaya yang besar. Salah satu ciri masyarakat miskin adalah derajat kesehatan yang rendah. Tingkat kesakitan juga berhubungan erat dengan kemiskinan (Sugiharto 2007).

Tingkat pendidikan sebagian masyarakat di Nusa Penida adalah tidak atau belum sekolah dengan jumlah sebesar 19.944 jiwa atau sebesar 39\%. Jumlah masyarakat tamat SD sebesar 16.862 jiwa atau sebesar 33\%, sedangkan masyarakat tamat SLTP sebesar 5.742 jiwa atau sebesar 11\% dan tamat SLTA sebesar 6.160 jiwa atau sebesar 12\% (Gambar 5). Tingkat pendidikan formal orangtua berpengaruh terhadap konsumsi keluarga. Pendidikan dapat merubah sikap dan perilaku masyarakat dalam memenuhi kebutuhan. Pendapatan yang tinggi memberikan peluang lebih besar untuk memilih jenis dan jumlah pangan yang baik.

Kemudahan memasukkan anak ke jenjang pendidikan tidak menjadi kendala dengan nilai skor rata-rata 3 . Dilihat dari segi biaya, jarak maupun proses penerimaan mudah, meskipun ada beberapa desa yang hanya memiliki sarana sekolah sampai jenjang 
tertentu. Kelengkapan seluruh jenjang pendidikan sudah tersedia di Pulau Nusa Penida, termasuk sarana perguruan tinggi terbuka jarak jauh.Jumlah masyarakat yang tamat jenjang Diploma sebesar 1.087 jiwa atau sebesar 2\% dan masyarakat tamat S1 sebesar 1.266 jiwa atau sebesar 3\%. Adanya program bebas biaya pendidikan sampai jenjang SLTA dari pemerintah sangat membantu untuk mempermudah masyarakat menyekolahkan anak-anaknya. Pendidikan merupakan salah satu sarana untuk meningkatkan kecerdasan dan keterampilan. Peningkatan dalam bidang pendidikan dapat mengeluarkan masyarakat dari kemiskinan. Tingkat pendidikan yang rendah merupakan hambatan dalam memperoleh pekerjaan. Masyarakatyangberpendidikan rendahdan tidak memiliki keterampilan khusus biasanya hanya mendapatkan pekerjaan yang banyak melibatkan aktivitas fisik dengan upah yang kecil sehingga kesejahteraan hidup mereka menjadi rendah.

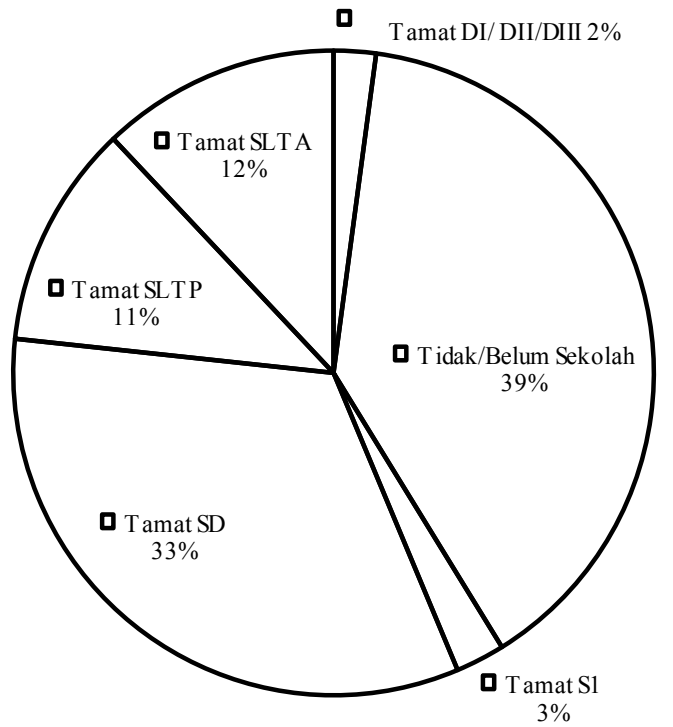

Gambar 5. Status pendidikan masyarakat di Pulau Nusa Penida

\section{Simpulan}

Berdasarkan analisis yang dilakukan dapat disimpulkan bahwa sebesar $90 \%$ masyarakat memiliki rata-rata tingkat kesejahteraan sedang, 3,3\% berada dalam tingkat kesejahteraan tinggi dan 6,7\% berada dalam tingkat kesejahteraan rendah. Kontribusi pendapatan masyarakat dari sektor wisata bahari rata-rata mencapai $36 \%$. 
Hal ini menunjukkan bahwa kegiatan wisata bahari di kawasan pesisir Pulau Nusa Penida memberikan kontribusi positif terhadap kesejahteraan masyarakat disekitarnya. Wisata bahari yang terjadi di Pulau Nusa Penida menjadi sektor yang dapat memberikan kontribusi terhadap kemajuan ekonomi, penciptaan lapangan pekerjaan dan pengurangan kemiskinan yang selanjutnya menjadi prioritas pembangunan.

\section{DAFTAR PUSTAKA}

Badan Pusat Statistik. 2011. Survei Indikator Pembangunan Manusia Kabupaten Semarang Tahun 2011.

2015. Statistik Daerah Kecamatan Nusa Penida 2015. Bali (ID): Badan Pusat Statistik Kabupaten Klungkung.

[Disparda] Dinas Pariwisata Pemerintah Provinsi Bali. 2016. Distribusi Kedatangan Wisatawan ke Bali Setiap Bulan Tahun 2008-2017.

Ferdinandus AM dan Suryasih IA. 2014. Studi Pengembangan Wisata Bahari untuk Meningkatkan Kunjungan Wisatawan di Pantai Natsepa Kota Ambon Provinsi Maluku. Jurnal Destinasi Pariwisata Vol. 2 No. 2.

Keputusan Menteri Kelautan dan Perikanan Nomor 24 Tahun 2014 Tentang Kawasan Konservasi Perairan Nusa Penida Kabupaten Klungkung di Provinsi Bali.

Kusnadi. 2002. Konflik Sosial Nelayan: Kemiskinan dan Perebutan Sumberdaya Perairan. Yogyakarta (ID): Lkis.

Megawangi R. 1994. Gender Perspectives in Early Childhood care and Development in Indonesia. Indonesia: The consultative group on early childhood care and development.

Muflikhati I., Hartoyo S., Ujang F., Achmad., Puspitawati H. 2011. Kondisi Sosial Ekonomi dan Tingkat Kesejahteraan Keluarga: Kasus di Wilayah Pesisir Jawa Barat. Bogor (ID): Institut Pertanian Bogor. Jurnal Ilmu Keluarga dan Konsumen Program Studi Gizi Masyarakat Dan Sumberdaya Keluarga.

Peraturan Daerah Provinsi Bali Nomor 16 Tahun 2009 Tentang Rencana Tata Ruang Wilayah (RTRW) Provinsi Bali.

Purbadharmaja IB., Sukarsa M., Indrajaya IGB., Yogiswara W., Apriliani PD. 2014. Profil Penduduk Miskin di Desa-Desa Pesisir Nusa Penida, Kabupaten Klungkung. Jurnal Buletin Studi Ekonomi, Vol. 19, No. 1. 
Shinta Y. 2008. Analisis Alokasi Pengeluaran dan Tingkat Kesejahteraan Masyarakat Pesisir Kabupaten Indramayu. Bogor (ID): Institut Pertanian Bogor.

Sugiharto E. 2007. Tingkat Kesejahteraan Masyarakat Nelayan Desa Benua Baru Ilir Berdasarkan Indikator Badan Pusat Statistik. EPP.Vol.4.No.2.

Undang-Undang Republik Indonesia Nomor 11 Tahun 2009 Tentang Kesejahteraan Sosial.

UNWTO. 2013. International tourism to continue robust growth in 2013. Diakses dari (http://media.unwto.org/press-release/201301-28/international-tourism-continue-robust-growth-2013) pada tanggal 9 Maret 2017.

Welly M., Sanjaya W., Primaoktasa D., Putra IP., Tatas MJ. 2011. Profil Wisata Bahari Nusa Penida Kabupaten Klungkung, Provinsi Bali. Bali (ID): Coral Triangle Center (CTC). 